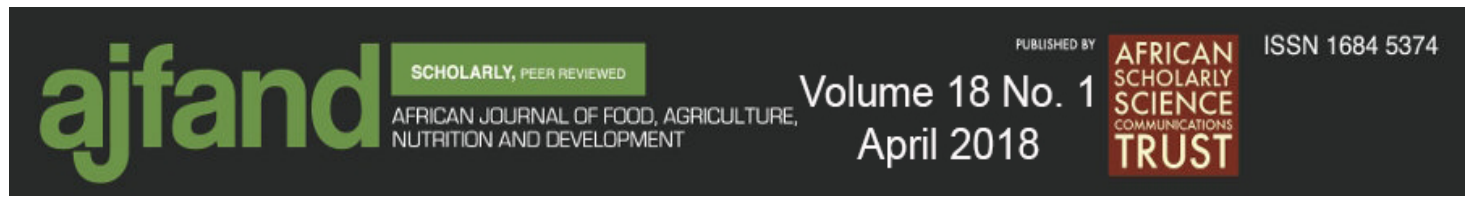

Afr. J. Food Agric. Nutr. Dev. 2018; 18(1): 13074-13094

DOI: 10.18697/ajfand.81.16640

\title{
LIVELIHOOD ACTIVITIES AND SKILLS IN RURAL AREAS \\ OF THE ZAMBEZI REGION, NAMIBIA: \\ IMPLICATIONS FOR POLICY AND POVERTY REDUCTION
}

\author{
Kamwi JM ${ }^{*}$, Chirwa PWC ${ }^{2}$, Graz FP ${ }^{3,4}$, \\ Manda SOM ${ }^{5,6}$, Mosimane $\mathrm{AW}^{7}$ and $\mathrm{C}$ Kätsch ${ }^{2,8}$
}

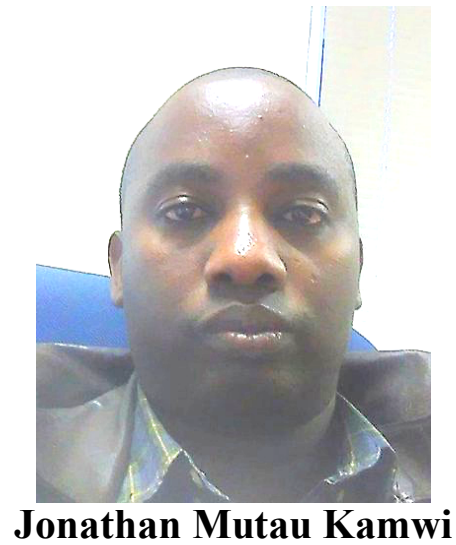

*Corresponding author E-mail address: mutauk@yahoo.co.uk

${ }^{1}$ Namibia University of Science and Technology, Department of Agriculture and Natural Resources Sciences, Private Bag 13388, Windhoek, Namibia

${ }^{2}$ Department of Plant and Soil Science, University of Pretoria, Private Bag X20, Hatfield 0028, Pretoria, South Africa

${ }^{3}$ Federation University Australia, University Drive, Mount Helen, VIC 3350, Australia

${ }^{4}$ School of Science and Engineering, University of Ballarat, P.O. Box 663, Mt. Helen 3353, VIC, Australia

${ }^{5}$ Biostatistics Unit, South African Medical Research Council, Private Bag X385,

Pretoria, 0001, South Africa

${ }^{6}$ School of Mathematics, Statistics and Computer Science, University of

KwaZulu-Natal, South Africa

${ }^{7}$ Neudamm Campus, University of Namibia, Private Bag 13301, Windhoek, Namibia

${ }^{8}$ Faculty of Resource Management, University of Applied Sciences and Arts

Hildesheim/Holzminden/Göttingen, Göttingen, Germany 


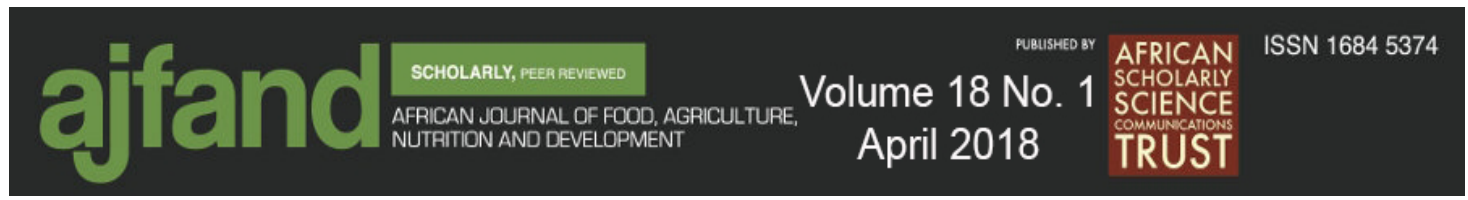

\section{ABSTRACT}

This paper examined livelihood activities and skill sets available within rural households in the Zambezi Region of Namibia. Specifically, the study addressed three key questions: (i) what livelihood activities do rural people pursue? (ii) what demographic factors are associated with these activities? and (iii) what measures can be taken to diversify and sustain income from these livelihood activities? In order to address these questions, semistructured interviews covering 424 households were used to collect the data. The questionnaire consisted of questions corresponding to the sustainable livelihood framework including (1) human assets (2) financial assets and major sources of income (3) physical and natural assets and (4) social assets. A series of logistic regressions were fitted from which the estimated odds ratios (y) were derived to ascertain the effect of the predictors on the livelihood activities and skills. Odds ratios were used to measure the magnitude of strength of association or non-independence between binary data values. The results showed that the use of various livelihood activities and skills in different combinations is of significant importance to rural livelihoods. Five percent of the respondents obtained income from only one source, with $95 \%$ of the respondents engaged in a combination of farming and non-farming activities. Most of the respondents had various reasons for diversifying into other activities vis-a-vis agricultural income, limited skills, large family size, availability of opportunities, seasonal nature of agricultural produce, favourable demand for goods and services or a combination of these. In addition, the results showed that gender, age, designation and education significantly $(\mathrm{p}<0.05)$ influenced the choice of household's skills. The study concludes that a combination of rural household activities and skills influenced by a variety of factors have led to improved livelihoods in the study area. For policy purposes, this suggests that state interventions in rural livelihood skill development can play a significant role in promoting more sustainable rural livelihoods.

Key words: livelihoods, activities, skills, households, regression, policy, Zambezi, Namibia 


\section{INTRODUCTION}

Livelihoods comprises of capabilities, assets and activities required for a means of living to define a specific household livelihood strategy [1]. The choice of a livelihood strategy that a household pursues is dependent on the socio-economic characteristics of the household including the skills which its members have at their disposal $[2,3]$. In this case, livelihood skills refer to capabilities, resources, and opportunities for pursuing individual and household economic goals such as income generation. Livelihood skills include technical and vocational abilities (carpentry, sewing, weaving, and gardening, among others) [4]. In this study, the researchers considered livelihood skills to include the physical ability of household members to carry out activities regardless of their educational levels. A number of livelihood skills are largely predetermined at birth into a specific socio-economic environment. Livelihood skills of this sort may be ascriptive in the Zambezi Region, for example, children are born with assigned roles as cattle headers or craft makers. A livelihood skill as socially defined is also a pervasive ascriptive determinant of livelihood activities [5]. The understanding of this issue is important in the Namibian context because livelihood skill development has been considered one of the important hindrances facing rural development [5].

Since the transition to democracy some 27 years ago, the Namibian government has addressed numerous challenges in the political, economic and social spheres. This has opened up opportunities for some households to venture into newer strategies by broadening the portfolio of livelihood activities available to them. Therefore, increasing the livelihood activities and skill set of rural households to broaden and strengthen the subsistence basis through diversification away from dependence on agricultural production has been on the policy agenda of the government [6]. Livelihood diversification has been defined as the process by which rural families construct a diverse portfolio of activities and social support capabilities in their struggle for survival and in order to improve their standards of living [7]. Diversification of livelihoods is essential in Namibia because of the semi-arid to arid conditions in which the highest rainfall areas are marginal for rain-fed crop production and drought is a common occurrence. More often than not, many communities in the Zambezi Region depend on agricultural and livestock production as part of their livelihoods. Productivity is, however, impacted heavily by droughts and floods which threaten the availability of food resources. This leads to poverty, which economically refers to the circumstances characterised by a lack of wealth, material goods and resources. Environmental degradation and climate change present risks to rural livelihoods that need to be managed and mitigated. This requires developing new, innovative strategies and livelihood skills to be able to learn about and use new environmentally friendly technologies and to improve rural livelihoods.

In the past, work has been done to analyze factors that govern decisions of communities to pursue different livelihood strategies in Namibia. For instance, Ashley and LaFranci [8] carried out assessment of livelihood strategies of rural households in the Zambezi Region (formerly called the Caprivi Region) and the implications for conservancies and natural resource management. However, the study did not critically look at the factors which influence the households' choice and the deployment of rural livelihood activities and skills in the Zambezi Region. There is, therefore, a need to develop predictive understanding on whichfactors influence the households' choice of livelihood activities 
and skills. This is particularly important for the design and effective adoption of sustainable livelihood strategies in future that can assist rural households and farm-based communities to cope with predicted changes in climate and other socio-economic conditions. As such, this study aimed to address three key questions: (i) what livelihood activities do rural people pursue? (ii) what demographic factors are associated with these activities? and (iii) what measures can be taken to diversify and sustain income from these livelihoods activities? An understanding of the significance and nature of livelihood skill development is of importance for policy makers in the design of potent rural development policies in the sub-Saharan African Region that might have similar demographic and socio-economic development issues. Specifically, this study will assist policy makers and stakeholders in mainstreaming livelihood activities and skill development strategies by understanding the livelihood systems.

\section{Conceptual framework}

In order to recognize the multidimensionality of rural livelihoods and human skills, it is essential to go further than quantitative measures of cash income or physical assets. A livelihood comprises of "assets (natural, physical, human, financial and social capital), the activities, and the access to these assets (mediated by institutional and social relations) that determine the livelihood of a household" [1]. Over 70\% of inhabitants of the Zambezi Region live in rural areas. Livelihood skill development is essential to strengthen the agriculture sector upon which the inhabitants are dependent and to ensure sustainable livelihoods. "A livelihood is sustainable when it can maintain or enhance its capabilities and assets without deterioration of the natural resources available, and cope with and recover from stresses and shocks and maintain or enhance its capabilities and assets both now and in the future" [9]. This stresses the means rather than the outcomes, and skills constitute a crucial means of livelihood performance.

The relationship between human populations and their environment in the pursuit of sustainable livelihoods has been an area of contention [10]. For instance, Carter and May [11] found that poor and non-poor households derive their livelihoods from distinct activities. Their studies reported that wage income earners are relatively non-poor than those that depend on agriculture as their main source of income. On the other hand, nonfarm activities play an important role in rural households' incomes and livelihoods and by influencing agricultural activities with potential implications for sustainability [12].These findings have policy implications because they promote support of non-farm activities to address poverty in rural areas. Most research works have been carried out at macro levels, however, micro level analysis is critical as households play a vital role in natural resource use, and understanding this linkage is important for appropriate policy interventions. Several studies have used the sustainable livelihood framework (SLF) to analyse rural livelihoods [1, 8, 9]. The SLF analyses livelihood based on natural resources and is comprised of five different capitals or assets-human assets, natural assets, financial assets, social assets and physical assets [9]. In the present study, the SLF was employed because it provides a holistic perspective in the analysis of livelihoods to identify those issues and subject areas where an intervention could be strategically important for effective livelihood improvement. Within the SLF, human assets (which include livelihood skill development) constitute an area of interest in the present study. 


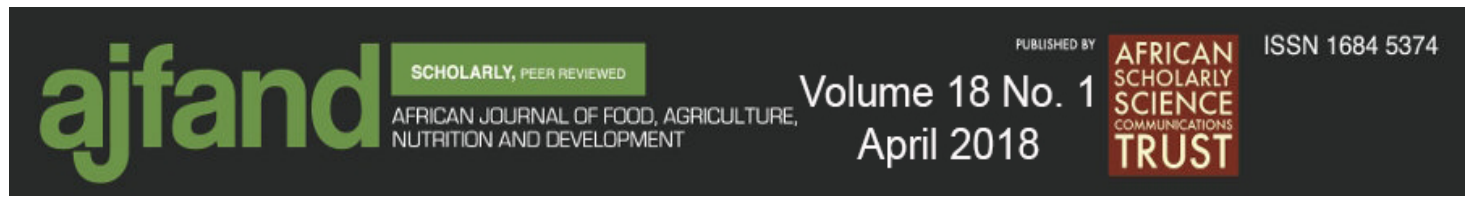

The SLF was applied in this study to assess the changes in the livelihoods of communities attributable to their skills. The framework states that within a particular vulnerability context, people deploy natural assets, financial assets, social assets and physical assets in variable combinations, within circumstances influenced by institutional structures and processes in order to pursue diverse livelihood strategies. These assets provide information on a household's structural income status and underlying welfare and are not subject to short-term fluctuations of income and consumption [13].

\section{METHODOLOGY}

\section{Study area}

The study was carried out in the Kongola and Sibbinda Constituencies of the Zambezi Region, which is located in the northeast of Namibia and covers an area of 616,600 ha (Figure 1). The Zambezi Region shares borders with Angola, Botswana, Zambia and its administrative capital is Katima Mulilo. The study focussed on the Kongola and Sibbinda constituencies because they are the most wooded regions of the Zambezi where natural resources play an important role in sustaining livelihoods. Other constituencies in the Zambezi Region such as Kabbe, Katima Mulilo and Linyanti were not covered in this study because they were flooded and the inhabitants were displaced during the study period. The landscape of the Kongola and Sibbinda constituencies is topographically homogenous, with an altitude of about $950 \mathrm{~m}$ above sea level, and a semi-tropical climate with alternating dry and wet seasons. Mean annual precipitation ranges from $650 \mathrm{~mm}$ in the western parts of the region to $900 \mathrm{~mm}$ in the east, mostly falling between October and March with a marked dry season between May and September. The annual gross evaporation ranges from 1,680 to $1,820 \mathrm{~mm} /$ year [14]. The soil is for the most part is sandy-loam whereby sandy dunes are found in the western part of the study area [15]. The vegetation is classified as woodland savanna and is largely comprised of Baikiaea plurijuga, Guibourtia coleosperma, Pterocarpus angolensis, Burkea africana and Dialium englerianum [16, 17]. The population of the Zambezi Region is approximately 80,000 of which about 57,000 people live in rural areas [18]. In 2010, the population in Kongola constituency was 5,658 (of which 2,797 were females and 2,861 males). On the other hand, the total population in Sibbinda was 10,182 (of which 5,084 were females and 5,098 males) [18]. The number of rural households in the Kongola and Sibbinda constituencies was 3,835 in 2010 [18]. Household economy is mostly agriculture based. 

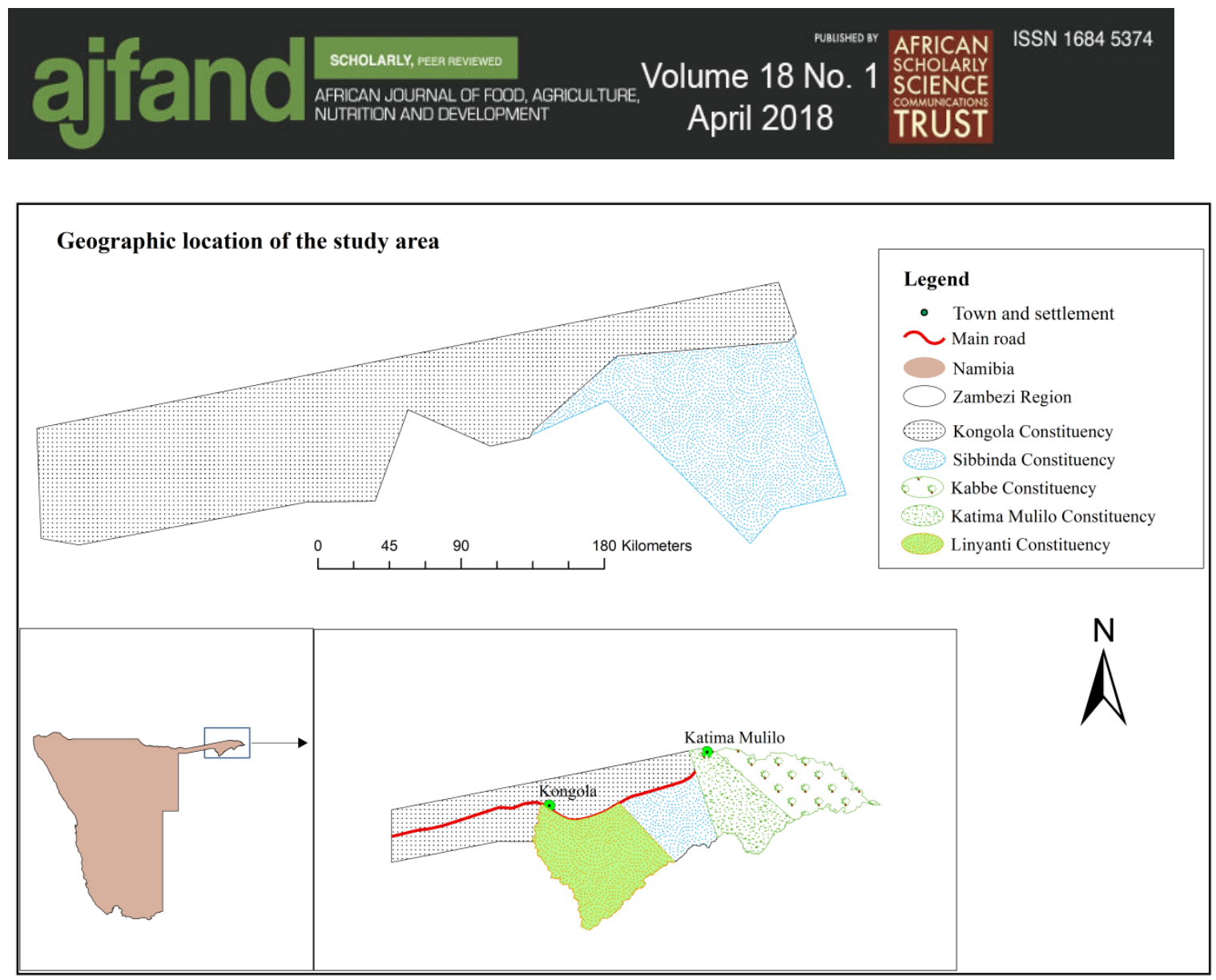

Figure 1: Location of study area

\section{Semi-structured questionnaire design}

The interviews were carried out using semi-structured questionnaires that included closed-ended questions for the collection of socio-economic data. The questionnaire consisted of four assets of the SLF namely: (1) human assets; (2) financial assets; (3) physical and natural assets; and (4) social assets. This was aimed at collecting data to characterize rural livelihoods, with particular focus on the activities and skills in the study area. The questionnaire was pre-tested and adjusted before the interviews of the sampled households. Respondents to the survey were not identified by name or location in order to maintain confidentiality. Each interview lasted an average of 45 minutes.

\section{Sampling framework}

A household was used as the basic unit of the survey and the household head was the unit of observation. In this regard, a household was defined as a group of people living together, making common arrangements for food and other essentials for a living [19]. In this case, a household would include people living in nearby houses but food prepared in a common kitchen is usually eaten together. Frequency counts of households and categories were checked for consistency to ensure accuracy. Villages were systematically selected to represent the villages in the Kongola and Sibbinda constituencies. Within the villages, households were randomly selected. The sample size was determined using a previously published formula that is commonly used in determining sample sizes when the numbers of participating households are known [20]. 


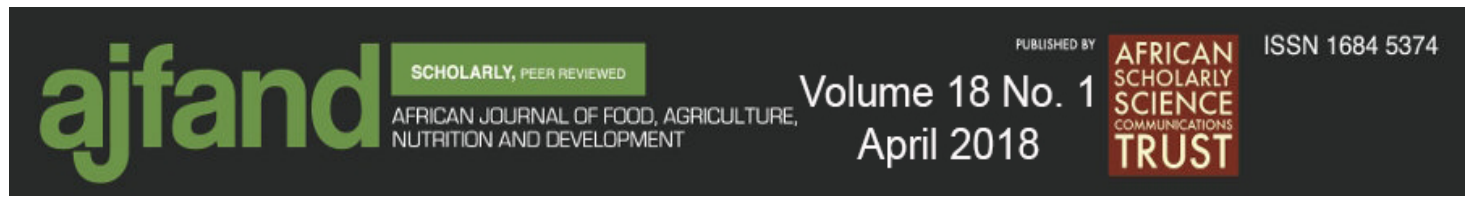

$\mathrm{S}=\frac{X^{2} N P(1-P)}{d^{2}(N-1)+X^{2} P(1-P)}$

Where $\mathrm{S}=$ required sample size; $\mathrm{X}^{2}=$ the table value of Chi-square for 1 degree of freedom C.L (3.841); $\mathrm{N}=$ the population size; $\mathrm{P}=$ population proportion (of 0.50 since this would provide the maximum sample size); $d=$ the degree of accuracy expressed as a proportion of 0.05 .

A total sample of 424 households were subsequently interviewed (142 in Kongola and 282 in Sibbinda constituencies based on the proportion of households in the two areas). This sample size was considered sufficient to provide perspectives on livelihood activities and skills in the rural areas [21,22]. In addition, this sample size took logistical considerations and financial constraints into account.

\section{Data analysis}

Questionnaire data were processed, coded and analysed using the Statistical Package for Social Sciences (SPSS) software version 19. Descriptive statistics were used to characterize socio-economic variables. The Pearson's Chi Square analysis was used to determine associations between the variables that constitute the livelihood activities and skills of respondents. Multinomial logistic regression was used to characterise the relative importance of livelihood activities. There are five broad categories of explanatory variables that influence household choices [23]. These include: household preferences, resource endowments, market incentives, risk and uncertainty and biophysical characteristics. Many of these factors cannot be measured directly. They are, however, included in demographic and socioeconomic variables such as gender, age, level of education and designation. The regressors (gender; age; level of education; designation; and marital status) were the same across all livelihood activities and skills for each observation. Table 1 provides the description of the variables in the logistic regression.

Other factors which could have improved regression estimates such as - what parents did, ethnicity, distance from towns and income level were not available at the scope of the study and were thus not included. A series of logistic regressions were fitted from which the estimated odds ratios (y) were derived to establish the effect of the predictors on the livelihood activities and skills. Odds ratios were used to evaluate the strength of association or non-independence between two binary data values. Odds ratio values specify changes in odds of livelihood activities and skills on independent variables (explanatory variables). Values between 0 and 1 indicate that an increase in the values of independent variables leads to a decrease in possibility of carrying out specific livelihood activities and the possession of certain livelihood skills. Values above 1 indicate that an increase in values of independent variables leads to an increase in probability of undertaking specific livelihood activities and the possession of certain livelihood skills. Of note is that livelihood activities pursued by households are a function of livelihood skills that are possessed by household heads. 


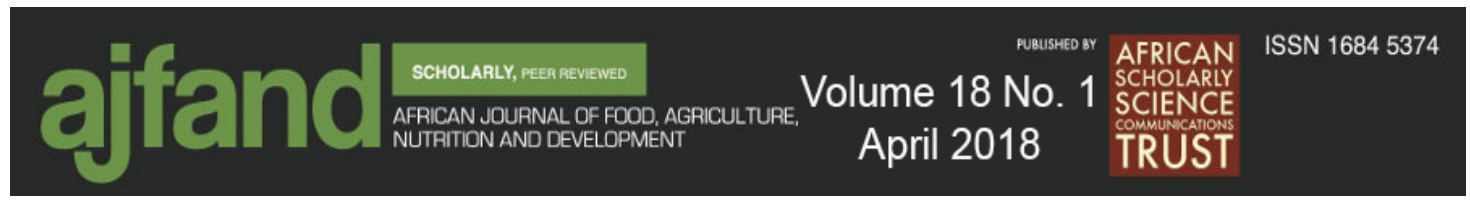

\section{Specification of the logistic regression model}

The decision to adopt livelihood activities can be viewed as being driven by how much utility a household gains from its decision. Multinomial dependent variable models are the most appropriate in which observed discrete activities are as a result of optimizing behaviour where the decision maker has 2 or more alternatives. Therefore, in order to categorize determinants of the household choice to deploy various livelihood activities in the study area, it was assumed that a rational household will select among seven mutually exclusive activities, which provides the maximum utility. Utility is viewed as an unobserved index determined by a set of explanatory variables that an individual household uses to rank a set of decision alternatives. For each of the activities, the household was categorised as either equal to 1 if that household had opted for the livelihood activity choice and 0 if that household had not opted for the livelihood activity choice. Thus, in a household, the sum of this variable ranged from 0 to 5, depending on the number of livelihood activities indicated. Each indicator was taken as a binary outcome and logistic regression was used to model explanatory variables including gender (male $=1$; female $=2$ ); age group; level of education; designation; and marital status. In the logistic regression analyses, dummy variables were constructed for these categories with the last category used as a reference. Livelihood activities (dependent variables) used for modelling include: cropping and livestock rearing; home construction; gardening; weaving; wood carving; fishing; and traditional medicine. The Chi-square test at $\alpha=0.05$ significance level was used to assess the goodness of fit of the models. Livelihood activities such as sewing, hunting, craft making and carpentry were not included in the logistic regression model because they were mentioned by only few respondents, which made them insufficient for inclusion in the models.

\section{RESULTS}

\section{Demographic characteristics}

An average rural household in the study area consists of 5 people. Among the 424 households, $29 \%(\mathrm{n}=124)$ were headed by men and $71 \%(\mathrm{n}=300)$ by women. Within the households interviewed, $25 \%(\mathrm{n}=105)$ of the respondents attended grade $1-7$ and $55 \%(\mathrm{n}=233)$ grade $8-12$ and were literate, based on their ability to read and write. However, $20 \%(n=86)$ of the respondents never attended school. This implies that most of the respondents have some form of formal education or the other. With regards to their marital status, $56 \%(\mathrm{n}=238)$ of respondents were married, $27 \%(\mathrm{n}=116)$ single and $17 \%(\mathrm{n}=70)$ widowed or separated. In terms of the sources of incomes, piecework (also referred to as part-time jobs) was ranked as the most important source of income in the study area with a mean rank of 1.24 (see Figure 2). Agricultural income constituted the second highest ranked income source (1.12). Other income sources such as the seasonal sale of fish, reeds or thatching grass were the third most essential income sources (1.10). Even though most of households were headed by females who were married, the remittances from their husbands living away from home were ranked low (0.01) when compared to other sources of income. 

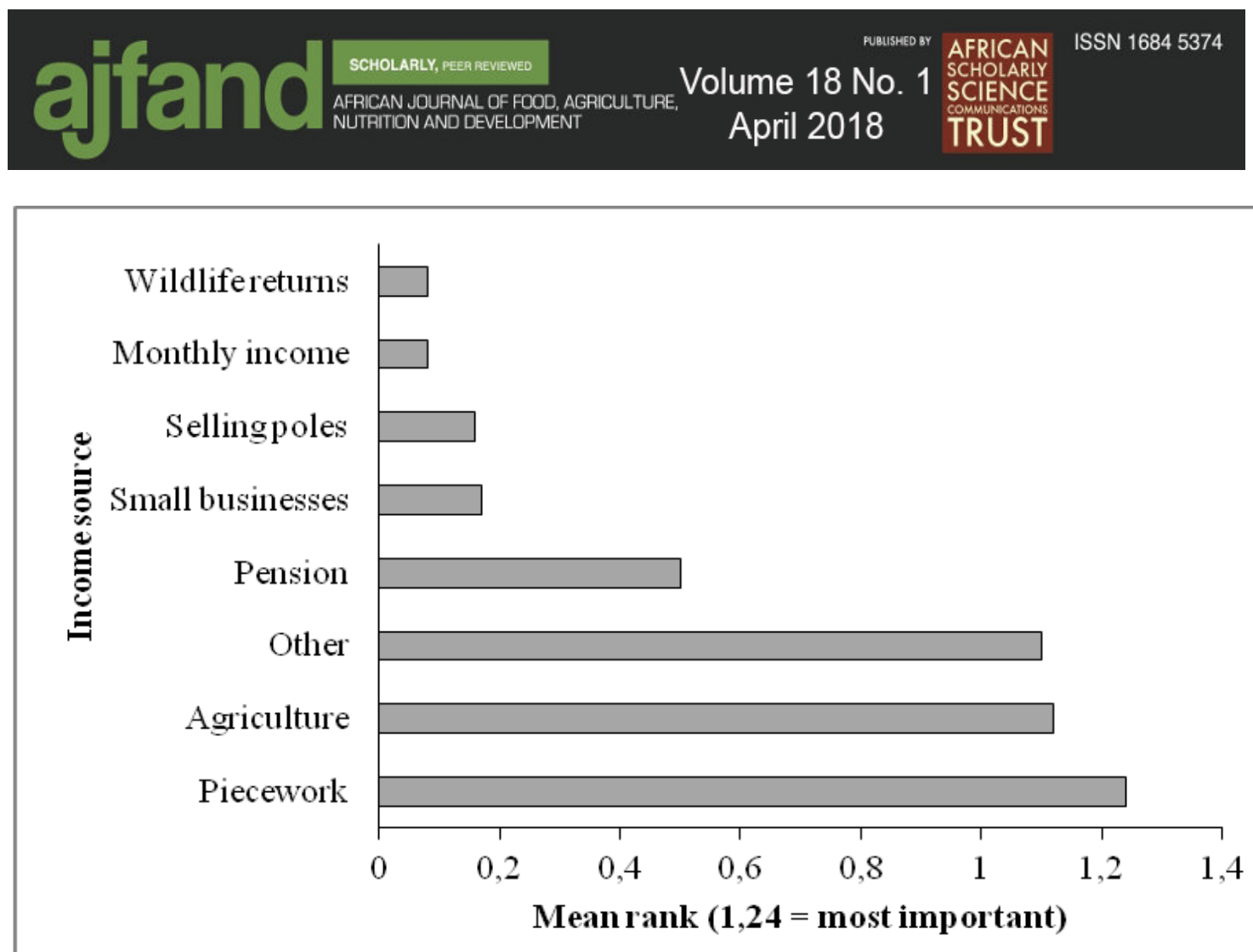

Figure 2: Importance of the sources of income in the study area

With regards to the propensity of respondents to opt for a diversity of income sources, the impact of gender was significant $(\mathrm{p}<0.05)$. About $29 \%$ of male respondents indicated that agriculture, particularly cattle sales were the priority source of income compared to their female counterparts $(71 \%)$. On the other hand, pole sales for construction area vital source of income for men (71\%) and less important for women $(29 \%)$. In contrast, $63 \%$ of women respondents regarded piecework as an important source of income when compared to the males (37\%). Small businesses such as the sale of groceries (household food items) were also regarded as an important source of income for women (58 \%) when compared to men (42\%). Also regarded important was income from pensions of household members or death benefits as reported by $77 \%$ women and $23 \%$ men.

\section{Prevalence of livelihood activities and skills}

Table 2 identifies 10 prevalent livelihood activities and skills by gender that are considered important in the study area. As evident from the table, cropping and livestock rearing, gardening and home construction were the most prevalent livelihood activities in the study area. On the other hand, cropping and livestock rearing, home construction and gardening were the most frequent activities mentioned by male respondents. Of importance is that the predominant livelihood activities among females and males are the same, but the priority order differed according to gender. Also, men were dominant in the livelihood activities such as wood carving, fishing and hunting. However, the importance of fishing and hunting activities has been put in check by the fact that the activities are rather specialized and the fact that fishing and hunting have become progressively restrictive.

Respondents were asked to indicate where they have acquired their divergent livelihood skills (Figure 3). Most females acquired their skills from conservancy activities followed 


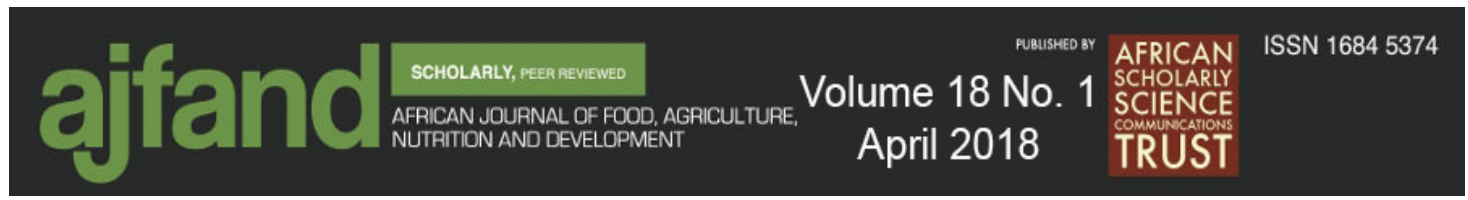

by cooperatives and in community forests. In this case, a conservancy is an area with distinct boundaries established to protect wildlife and their habitats. Conservancy members have rights over tourism operations. Community forestry activities include the sale of timber and non-timber products from designated community land areas. Although men also acquired most of their livelihood skills in the conservancy, their second important source of livelihood skills was from community forests and they acquired least skills in cooperatives as expected. Cooperatives are groups of people who are organised to produce different household items including food and the returns are pooled together for a common purpose in the community. The respondents received no formal instructions from the registered training institutions.

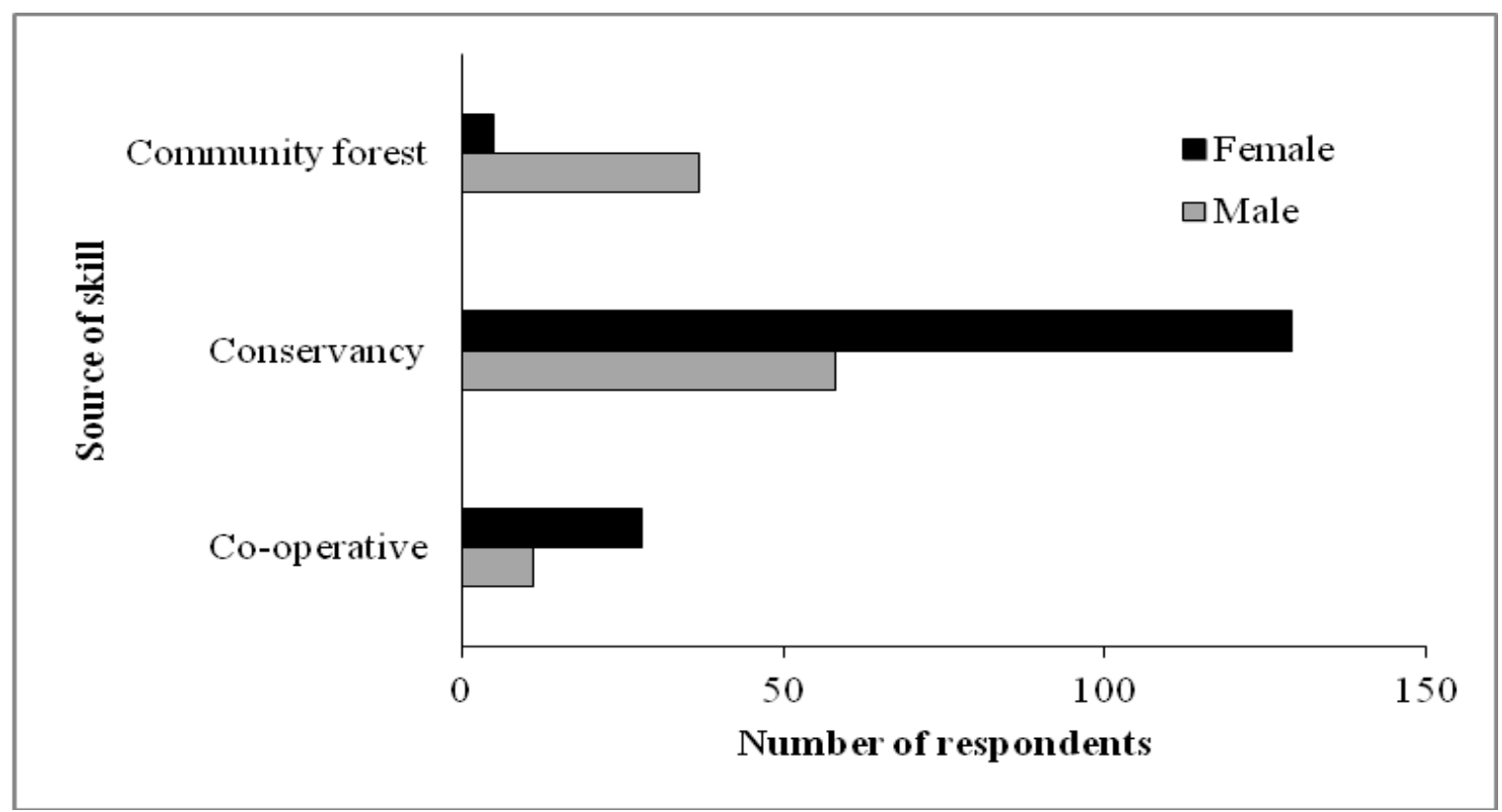

Figure 3: Frequency of livelihood skills by source in the study area

When asked on how to ensure that livelihood skills remain in their society, most respondents indicated that the inclusion of these livelihood skills into their culture is important (Table 3).

\section{Diversification of livelihood activities}

Results of livelihood diversification strategies by gender are provided in Table 4. It can be seen that livelihood diversification strategies are pursued by both males and females while others are gender specific. For instance, formal employment, agriculture, piecework, cuca chops and other activities are carried out by both male and females. On the other hand, the selling of poles, devils claw and conservancy are either carried out by males or females.

\section{Factors affecting the selection of livelihood activities}

Results of the logistic regression analysis of livelihood activities by rural households are provided in Table 5. The output of logistic regression models indicated that after adjusting for the effect of factors, gender and age significantly influenced choice of woodcarving livelihood activity $(\mathrm{p}<0.005)$. Despite the significant influence of age on 
wood carving, the odds reduced by a factor of 0.449 with a unit increase in age. However, there were no significant influences of marital status, designation and education on the woodcarving activity $(\mathrm{p}>0.005)$. Gardening was significantly influenced by designation and age $(\mathrm{p}<0.005)$. As expected, traditional medicine was significantly influenced by age $(p<0.005)$. Home construction was significantly influenced by education and age $(p<0.005)$ where the odds were 1.642 more likely with a unit increase in age; whereas fishing was significantly influenced by gender and marital status $(\mathrm{p}<0.005)$. Although no significant influence of age on fishing was found, the odds increased by a factor of 1.292 with a unit increase in age.

\section{DISCUSSION}

Livelihood activities and skills are fundamental to improve livelihood opportunities, decrease poverty, enhance employability, and promote sustainable development. Coordinated efforts by all sectors of the economy are crucial to build up an integrated approach that improves access to education and training to all rural households [5]. In particular, livelihood skill development in rural areas requires a mix of types of skills provision using innovative methods of delivery through social institutions. The patterns of income diversification among rural households in Namibia showed that majority of the households have fairly diversified income sources using a combination of livelihood activities and skills [5].

In terms of the ability to pursue different livelihood activities and skills, respondents were asked to list activities and skills available in their households. As expected, respondents indicated that they combine a variety of livelihood activities and skills to access new opportunities for income generation to improve their diverse livelihoods. Prominent livelihood activities and skills mentioned include cropping and livestock rearing, home construction and gardening, all three of which are part of the culture. However, other livelihood activities such as weaving, wood carving, fishing, traditional medicines, sewing, hunting, craft making and carpentry are flexible and easy to carry out. Consequently, rural households tend to employ them any time, despite their lower returns [24]. Analysis of the types of livelihood activities of respondents revealed that more than half were engaged in agriculture as their primary occupation, indicating that the skills associated with cropping and livestock rearing are predominant. This is expected as most households in rural areas in the Zambezi Region depend mainly on agriculture as their primary source of livelihood. However, literature has shown that diverse income portfolio creates more income and distributes income more evenly. Thus, it is easier to adopt the combined livelihood activities than switching full time between either of them [1]. In line with this, only $5 \%$ of the respondents obtained income from one source (cropping and livestock rearing), whilst $95 \%$ of the respondents engaged in a combination of farming and non-farming activities. Most of the respondents had various reasons for diversifying into other activities. Some of these reasons include limited agricultural income due to frequent droughts and pest attacks, limited skills, large family size, availability of opportunities, seasonal nature of agricultural produce, favourable demand for goods and services or a combination of these. 
The main reason for diversification reported by almost half of the respondents in the study area was limited agricultural income and limited livelihood skills. One of the men said "if I do not get good returns from my crop field, I must do other activities like home construction instead of wasting such an income opportunity". This phrase was repeatedly referred to in the local language as "kulilyata-lyata" meaning "I should check everywhere and take any opportunity which comes with considerable benefits". Education is one of the most important contributors of more remunerative and skilled employment in rural Africa [24]. As a result, education is a pathway for better-paid job opportunities that requires formal schooling. The significance of education, both formal academic education and workplace skills, for improving livelihood prospects is established by a great number of studies, and poverty is closely associated with low levels of education and lack of skills [25]. By implication, educated household heads were expected to understand better livelihood requirements and have the capacity to analyse the net benefits of activities before they make final adoption decisions. As such, they are likely to adopt more activities than the illiterate households.

Based on the logistic regression results, the odds ratio increased for gender in terms of woodcarving, traditional medicine, home construction and fishing livelihood activities. This is in line with previous work, which indicated that gender affects livelihood activities and skills, including the choice of income-generating activities (both farm and non-farm) due to culturally defined roles [26]. Thus, it becomes important for policymakers to understand the nature and patterns of household livelihood activities and skills, and distinguish the factors that drive households into non-farm activity, and thus inform gender development programs and policies. Differentiation of activities based on gender is an integral and inseparable part of rural livelihoods where men and women have different livelihood activities and skills, access to resources and opportunities. Woodcarving, for instance, is dominated by males in the study area. Also, in traditional African society, serious wood carving activities are always done by male folks. Similarly the researchers noted the increase in gardening activity and associated livelihood skills with an increase in age. The results suggest that age may be a determining factor of the type of livelihood activity that households are using and skills to be provided to specific community members because other skills such as home construction are more labour intensive and may be carried out by older members of the community. Results of the current study corroborate those that have been previously reported [27].

Despite the presence of significant influences of age to the traditional medicine activity, the odds ratio reduced by a factor of 0.442 , respectively. It is important to note that traditional knowledge includes medicinal uses of plants and traditional systems of medical diagnosis. Two thirds of the respondents who undertake the traditional medicine activity were women. Most people in the Zambezi Region, especially those living in rural communities do not have access to modern medicine and it is estimated that about $60 \%$ of the populace still prefer to solve their health problems by consulting traditional healers [5]. Besides, many rural communities have great faith in traditional medicine, particularly the inexplicable aspects as they believe that it is the wisdom of their forefathers which also recognises neglect of their socio-cultural and religious background by modern medicine. Significant influence of gender and age were found on the weaving activity $(p<0.05)$. This is because weaving is considered mainly a women activity, 
particularly elderly women who have few household chores. Weaving is also a less labour intensive activity. One of the female respondents said "even unskilled women like me have the opportunity to weave during the slack farming season". Gender and education significantly influenced the home construction and fishing activities. The possible explanation is that home construction and fishing activities are strenuous activities mainly carried out by men.

Notwithstanding the potential of investment in agriculture by the government, there has often been inadequate attention paid to the needs of rural communities in this regard. This result is in consonance with findings in other parts of sub-Saharan Africa where agricultural education and training in general has persistently failed to meet the needs of farmers because the range of skills needed by part-time farmers, subsistence producers and rural women, are often ignored or are poorly addressed [28]. Agricultural extension is also critical to move research from the lab to the field and to ensure a return on research investment by translating new knowledge into innovative practices to improve livelihoods. In order to improve skill development, alternative agricultural extension models that recognise other actors than traditional public extension services including agribusiness companies, non-governmental organisations, agro-dealers, producer organisations and farmer to farmer exchanges are required. For instance, agricultural extension can be contracted out to the private sector and non-governmental organisation or the farmer-to-farmer extension model which involves extension professionals training farmers in technologies and encouraging them to serve their communities voluntarily as community extension workers could be explored. This is in line with the suggestions by a number of countries in sub-Saharan Africa [29, 30].

However, rural households' access to education and training is often limited by financial barriers (such as training and transportation costs) and non-financial barriers (such as scarce education and training infrastructure and inflexible training schedules). On the other hand, the opportunity costs for education and training for poor rural children and adults may be too high to give up their income-generating activities and unpaid duties that help sustain their families. As shown by the results, many rural people did not attain higher levels of education. This reduces their access to technical and vocational training or other skills development offered by vocational training and higher education institutions. Similarly, a previous report [31] indicated that education level affects the use and reading materials by the users. Therefore, education level of the household head is vital in understanding and interpretation of information to achieve sustainable livelihoods through the use of innovative land management options. There is, therefore, a need to integrate skills development into rural development policies and strategies, such as agricultural policies, and entrepreneurship policies. Furthermore, there is a need to strengthen coordination and collaboration with the private sector in skills development to increase the relevance of training, and to improve and facilitate its delivery among rural households. The collaboration between government, non-governmental organisations and communities in a platform where they can harmonize their skills, capacities and resources is indispensable to facilitate effective capacity development in decentralization efforts. This will also enable communities set up their own capacity needs and aspirations based on what they envisage for their organization and community by sitting with the service providers at equal footings [32]. While access to good quality 


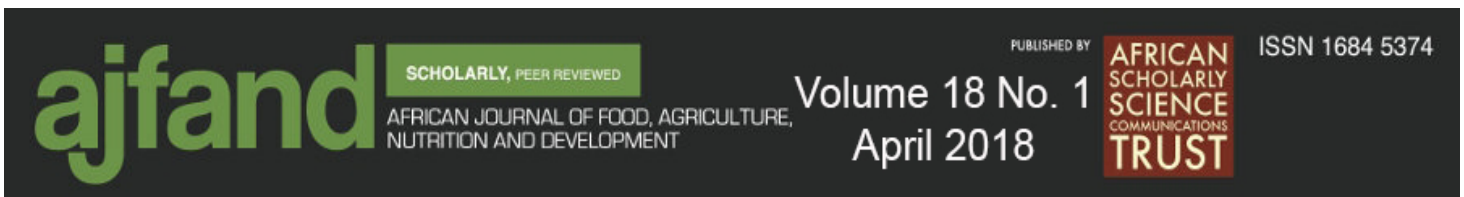

formal training is important, including innovative non-formal and informal skills training into national training systems is also important to improving skills provision in rural households.

\section{CONCLUSION}

Conclusively, this study has shown that a variety of livelihood activities and skills play an important role in augmenting farm-income, with most people adopting a combination of livelihood activities. The results of the study will contribute to the ongoing efforts to address issues of rural development in Namibia and other countries under similar socioeconomic conditions. The present study examined various livelihood activities pursued and prevalent livelihood skills in the study area. The study concluded that agriculture alone is not an adequate source of revenue for the rural households. The results suggest that the fight against poverty cannot be won with a mere focus on agricultural development. Therefore, promoting innovative livelihood activity and skill development may thus be an important strategy for supplementing the income of rural communities as well as sustaining equitable rural growth. This could be achieved through training programmes directed towards training in rural communities in livelihood skills that can be used in non-farm jobs in their vicinity. Results showed that much diversification exists among households, each deploying specific activities towards more resilient livelihood outcomes and non-farm work is a superior activity. The key finding of the study was that there are substantial differences in livelihood activities and skills, according to whether individuals are male or female, old or young, literate or illiterate. Therefore, there is a need to provide adequate training so that they may enhance their participation in higher income-generating activities. Such capacity building and training initiatives must fit within households' existing livelihood skill levels. Important to note is that practical literacy training is, however, valuable and it builds confidence and reduces the perception among illiterate households that they are excluded from the training process. Their involvement in more creative non-agricultural monetary activities should be enhanced. This can be done by promoting the non-agricultural sector by establishing essential infrastructural facilities for activities such as wood carving, medicine, carpentry and craft making. The policy implication of this study is that there is a need to further support livelihood activities and skills to contribute to poverty alleviation among the rural communities. Similar case studies should be conducted across various regions of Namibia and Africa in general, to understand how livelihood skills impact rural households to make informed decisions for sustainable livelihood development. Furthermore, the private sector should be encouraged to identify income-generating activities in the rural areas to enhance livelihood diversification activities and ultimately living standards. The inherent dichotomy in approach to livelihood activities and skill development need to be reflected in intervention design and implementation of livelihood projects and programmes. 


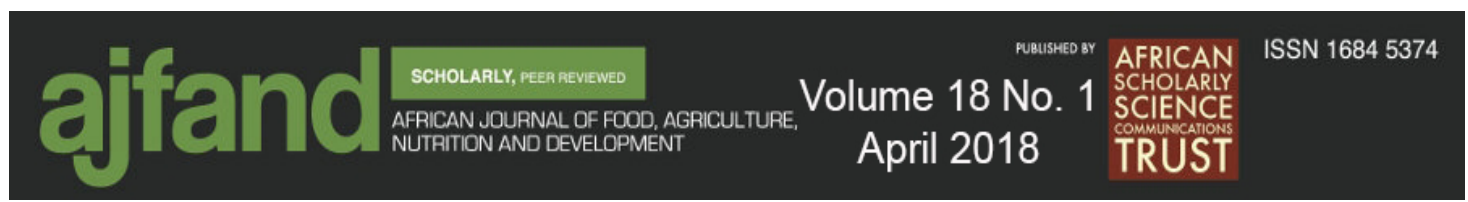

\section{ACKNOWLEDGEMENTS}

Thanks are due to the communities of Kongola and Sibbinda constituencies in the Zambezi Region for sharing their livelihood experiences with us. This research was supported by the University of Pretoria and the Ministry of Agriculture, Water and Forestry in Namibia. We are also grateful for the financial support from the Southern African Science Service Centre for Climate Change and Adaptive Land Management (SASSCAL) task 033. Last but not the least, we would like to express our appreciation to the Forestry extension officers in the Zambezi Region and all organisations and individuals who provided the necessary support including provision of secondary data. This research complies with the current laws of the Republic of Namibia. 


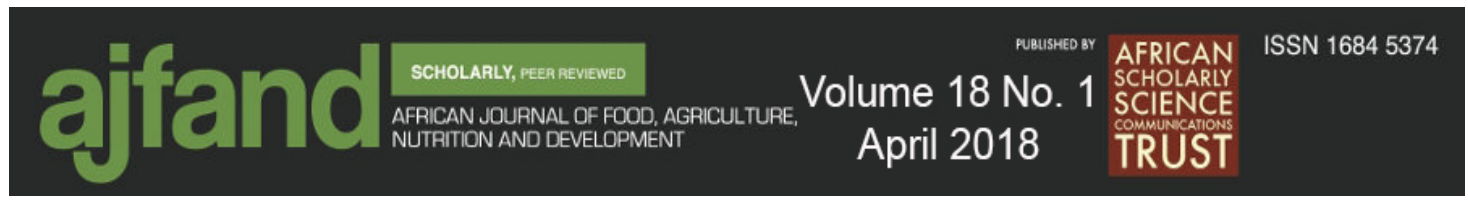

Table 1: Description of the variables in the multinomial logistic regression

\begin{tabular}{ll}
\hline Variable & Description \\
\hline Gender & Gender of the household head (if male 1; 0 if female) \\
Marital status & (Married, single, living together or widowed \\
Designation & Employed, unemployed, student and self-employed \\
Education & $\begin{array}{l}\text { This was measured as attainment of formal education (primary, secondary } \\
\text { and tertiary level) }\end{array}$ \\
Age & Age of household head (years) \\
\hline
\end{tabular}

Table 2: Prevalence of livelihood skills by gender

\begin{tabular}{lrr}
\hline Skill & Male & Female \\
\hline Wood carving & 36 & 3 \\
Gardening & 56 & 125 \\
Traditional medicine & 10 & 20 \\
Carpentry & 3 & 1 \\
Cropping and livestock rearing & 119 & 293 \\
Weaving & 6 & 56 \\
Home construction & 81 & 108 \\
Craft making & 5 & 8 \\
Sewing & 3 & 17 \\
Fishing & 21 & 10 \\
Hunting & 16 & 0 \\
\hline
\end{tabular}

Table 3: Suggestions on how to ensure that livelihood skills remain in the society

\begin{tabular}{lrr}
\hline Livelihood skill & Learning centres & Culture \\
\hline Wood carving & 8 & 38 \\
Gardening & 128 & 178 \\
Traditional medicine & 0 & 29 \\
Carpentry & 1 & 4 \\
Cropping and livestock rearing & 151 & 402 \\
Weaving & 10 & 61 \\
Home construction & 113 & 186 \\
Craft making & 3 & 13 \\
Sewing & 7 & 20 \\
Fishing & 2 & 31 \\
Hunting & 7 & 15 \\
\hline
\end{tabular}




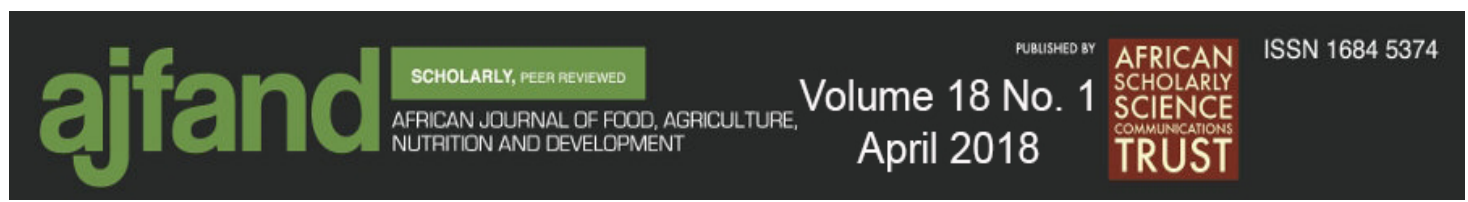

Table 4: Diversification of livelihoods by gender

\begin{tabular}{|l|c|l|c|c|c|c|c|c|}
\hline Gender & $\begin{array}{l}\text { Monthly } \\
\text { income/ } \\
\text { Employment }\end{array}$ & $\begin{array}{l}\text { Agriculture } \\
\text { (crops / } \\
\text { livestock) }\end{array}$ & $\begin{array}{l}\text { Selling of } \\
\text { poles }\end{array}$ & $\begin{array}{l}\text { Selling } \\
\text { of } \\
\text { Devils } \\
\text { claw }\end{array}$ & $\begin{array}{l}\text { Returns from } \\
\text { Conservancy } \\
\text { activities }\end{array}$ & $\begin{array}{l}\text { Piecework } \\
\text { (part-time } \\
\text { jobs) }\end{array}$ & $\begin{array}{l}\text { Cuca } \\
\text { shops }\end{array}$ & Other \\
\hline Male & 12 & 66 & 5 & 0 & 1 & 14 & 4 & 17 \\
\hline Female & 22 & 178 & 0 & 2 & 0 & 20 & 6 & 78 \\
\hline Total & 34 & 244 & 5 & 2 & 1 & 34 & 10 & 94 \\
\hline
\end{tabular}




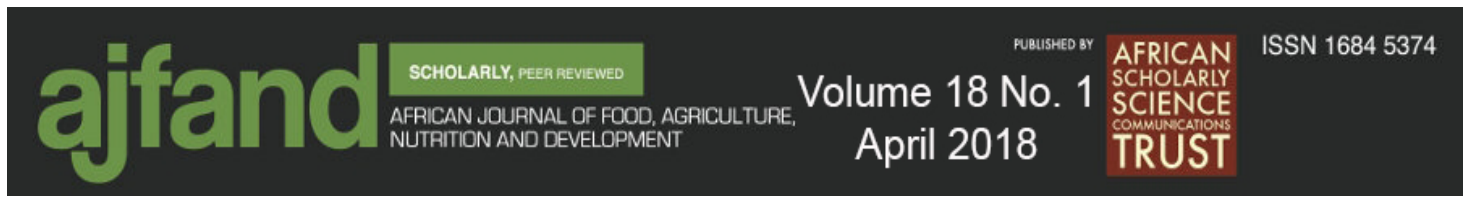

Table 5: Factors affecting the choice of households to pursue specific livelihood activities and skills

\begin{tabular}{|c|c|c|c|c|c|}
\hline Livelihood activity & $\begin{array}{l}\text { Independent } \\
\text { variable }\end{array}$ & $\begin{array}{l}\text { Odds } \\
\text { ratio }\end{array}$ & Lower & Upper & $p$ value \\
\hline \multirow[t]{5}{*}{ Wood carving } & Gender & 40.937 & 12.037 & 139.222 & $0.000^{*}$ \\
\hline & Marital status & 1.474 & 0.792 & 2.742 & 0.221 \\
\hline & Designation & 1.794 & 0.630 & 5.107 & 0.273 \\
\hline & Education & 1.081 & 0.840 & 1.390 & 0.545 \\
\hline & Age & 0.449 & 0.236 & 0.853 & $0.015^{*}$ \\
\hline \multirow[t]{5}{*}{ Gardening } & Gender & 0.999 & 0.627 & 1.920 & 0.996 \\
\hline & Marital status & 1.182 & 0.934 & 1.497 & 0.165 \\
\hline & Designation & 0.451 & 0.213 & 0.955 & $0.038^{*}$ \\
\hline & Education & 1.071 & 0.943 & 1.216 & 0.293 \\
\hline & Age & 1.937 & 1.450 & 2.588 & $0.000 *$ \\
\hline \multirow[t]{5}{*}{ Traditional medicine } & Gender & 1.532 & 0.655 & 3.583 & 0.325 \\
\hline & Marital status & 0.849 & 0.580 & 1.242 & 0.398 \\
\hline & Designation & 4.014 & 0.502 & 32.079 & 0.190 \\
\hline & Education & 1.002 & 0.818 & 1.228 & 0.984 \\
\hline & Age & 0.442 & 0.214 & 0.913 & $0.027^{*}$ \\
\hline \multirow{5}{*}{$\begin{array}{l}\text { Cropping and livestock } \\
\text { rearing }\end{array}$} & Gender & 0.604 & 0.164 & 2.222 & 0.448 \\
\hline & Marital status & 0.644 & 0.295 & 1.406 & 0.269 \\
\hline & Designation & 1.604 & 0.293 & 8.776 & 0.586 \\
\hline & Education & 1.029 & 0.715 & 1.481 & 0.877 \\
\hline & Age & 1.909 & 0.685 & 5.324 & 0.216 \\
\hline \multirow[t]{5}{*}{ Weaving } & Gender & 0.199 & 0.078 & 0.510 & $0.001 *$ \\
\hline & Marital status & 1.155 & 0.880 & 1.517 & 0.299 \\
\hline & Designation & 0.971 & 0.291 & 3.240 & 0.961 \\
\hline & Education & 0.832 & 0.714 & 0.969 & $0.018^{*}$ \\
\hline & Age & 0.245 & 0.131 & 0.460 & $0.000^{*}$ \\
\hline \multirow[t]{5}{*}{ Home construction } & Gender & 3.260 & 2.025 & 5.248 & $0.000^{*}$ \\
\hline & Marital status & 1.085 & 0.854 & 1.378 & 0.503 \\
\hline & Designation & 0.769 & 0.357 & 1.657 & 0.503 \\
\hline & Education & 1.143 & 1.005 & 1.301 & $0.041^{*}$ \\
\hline & Age & 1.642 & 1.224 & 2.201 & $0.001 *$ \\
\hline \multirow[t]{5}{*}{ Fishing } & Gender & 7.288 & 2.967 & 17.901 & $0.000 *$ \\
\hline & Marital status & 0.600 & 0.372 & 0.970 & $0.037^{*}$ \\
\hline & Designation & 0.677 & 0.237 & 1.938 & 0.468 \\
\hline & Education & 0.946 & 0.745 & 1.201 & 0.648 \\
\hline & Age & 1.292 & 0.731 & 2.283 & 0.378 \\
\hline
\end{tabular}

*Significant at $5 \%$ 


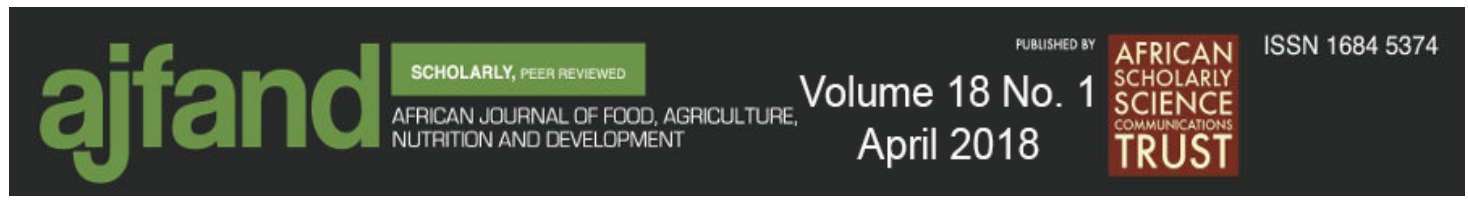

\section{REFERENCES}

1. Ellis F Rural livelihoods and diversity in developing countries. Oxford: Oxford University Press, 2000.

2. Jianchu X, Fox J, Vogler JB, Peifang Z, Yongshou F and Y Lixin Land-use and landcover change and farmer vulnerability in Xishuangbanna Prefecture in South-western China. Environmental Management. 2005; 36(3): 404-413.

3. Sen A Poverty and famines: An essay on entitlement and deprivation. Oxford: Oxford University Press, 1981.

4. Conway G Sustainable rural livelihoods: practical concepts for the $21 \mathrm{st}$ century', IDS. Discussion Paper 296, Brighton: IDS, 1992.

5. Kamwi JM, Chirwa PWC, Manda SOM, Graz FP and C Kätsch Livelihoods, land use and land cover change in the Zambezi Region, Namibia. Population and Environment. 2015; 36: 1-24.

6. Government of Namibia. Fourth National Development Plan (NDP4). 2012, 2012/13 - 2016/2017. www.npc.gov.na

7. Ellis F Household strategies and rural livelihood diversification. Journal of Development Studies, 1998; 35(1): 1-38.

8. Ashley C and C LaFranci Livelihood strategies of rural households in Caprivi: Implications for conservancies and natural resource management. Research Discussion Paper No. 20. Directorate of Environmental Affairs. Ministry of Environment and Tourism. Namibia, 1997.

9. DFID. Sustainable livelihoods guidance sheets. Department of International Development, 1999. http://www.livelihoods.org/info/info_guidancesheets.html Accessed: 4 May 2016.

10. Charles T and A Hailemariam The Demographic Transition and Development in Africa: The Unique Case of Ethiopia. Springer, 2011.

11. Carter $\mathbf{M}$ and $\mathbf{J}$ May Poverty, livelihood and class in rural South Africa. World Development, 1999; 27(1): 1-20.

12. Kuiper M, Meijerink G and E Derek Rural Livelihoods: Interplay Between Farm Activities, Non-farm Activities and the Resource Base. International Trade and Development, Public Issues Division Agricultural Economics Research Institute (LEI) - Wageningen UR The Netherlands, 2006.

13. Filmer D and LH Pritchett Estimating wealth effects without expenditure data-Or tears: An application to educational enrolments in states of India. Demography. 2001; 38(1): 115-132. 


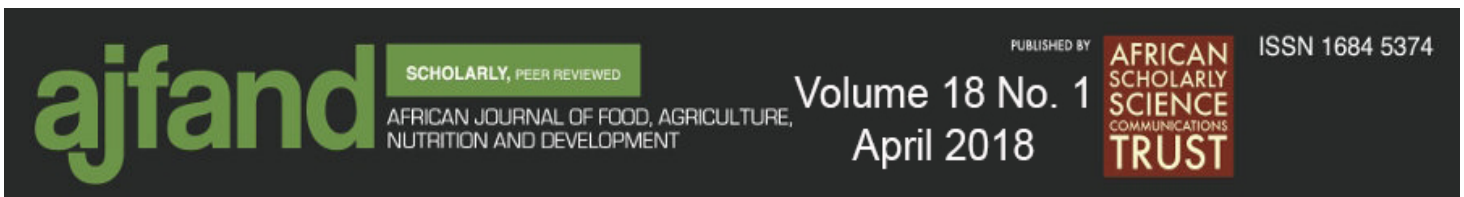

14. Mendelsohn J, Jarvis A and T Robertson Atlas of Namibia: A portrait of the Land and its people. Ministry of Environment and Tourism, Windhoek, Namibia, 2009.

15. Mendelsohn $\mathbf{J}$ and $\mathbf{C}$ Roberts An environmental profile and atlas of Caprivi. Ministry of Environment and Tourism, Directorate of Environmental Affairs, Windhoek, Namibia, 1997.

16. Giess W A preliminary vegetation map of Namibia. Third revised edition. Dinteria. 1998; 4: 1-112.

17. Kamwi JM and C Kätsch Using high-resolution satellite imagery and double sampling as a cost-effective means of collecting forest inventory data-the case of Hans Kanyinga Community Forest, Namibia. Southern Forests. 2009; 71(1): 49-58.

18. Central Bureau of Statistics. An atlas of Namibia's population: Monitoring and understanding its characteristics. Windhoek: Central Bureau of Statistics, 2010 .

19. FAO. A system of integrated agricultural censuses and surveys. Italy: World Programme for the Census of Agriculture, 2010.

20. Krejcie RV and DW Morgan Determining Sample Size for Research Activities, Educational and Psychological Measurement. Duluth: University of Minnesota, 1970.

21. Hetherington JC Samples? What Shape? How large? Scottish Forestry. 1975; 29: $260-267$.

22. Turyahabwe $\mathbf{N}$ Local capacity to manage a decentralized system of governance: The case of Uganda. PhD thesis, Stellenbosch University. 2006, 199.

23. Pattanayak SK, Mercer DE, Sill EO Yung JC and K Cassingham Taking Stock of Agroforestry Adoption Studies. Research Triangle Institute, 2002.

24. Barrett CB, Reardon $\mathbf{T}$ and $\mathbf{P}$ Webb Non-farm income diversification and household livelihood strategies in Rural Africa: Concepts, dynamics, and policy implications. Food Policy. 2001; 26: 315-331.

25. Beall J Thoughts on Poverty from a South Asian Rubbish Dump: Gender, Inequality and Household Waste. IDS Bulletin. 1997; 28: 3.

26. Galab S, Fenn B, Jones N, Raju DSR, Wilson I and MG Reddy Livelihood Diversification in Rural Andhra Pradesh: Household asset portfolios and implications for poverty reduction working paper no. 34, 2002. 


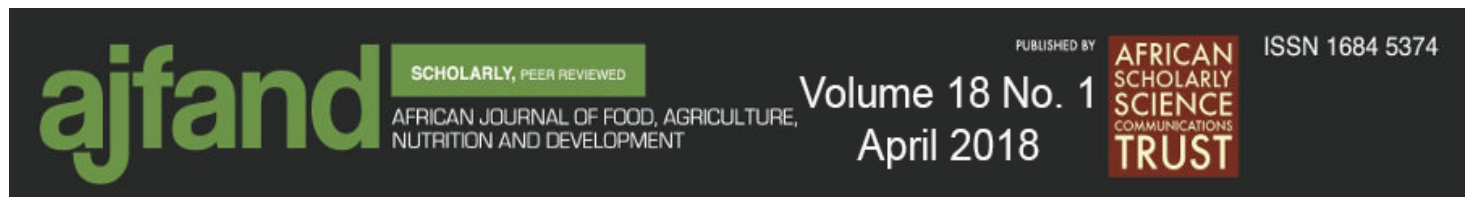

27. ILO. Skills for rural employment and development. Policy Brief (Geneva). 2014. Accessed: 20 March 2016.

28. Wallace I, Mantzou K and P Taylor Policy options for agricultural education and training in sub-Saharan Africa: report of a preliminary study and literature review. Agricultural Extension and Rural Development Department, University of Reading, Working Paper 96/1, 1996.

29. Muok B, Kimondo J and I Atsushi Farmer to Farmer Extension: Development Institute. Experience in Drylands, Kenya, 2001.

30. Kundhlande G, Franzel S, Simpson B and E Gausi Farmer-to-farmer extension approach in Malawi: A survey of organizations using the approach ICRAF Working Paper number 183. Nairobi, World Agroforestry Centre. 2014, DOI: http://dx.doi.org/10.5716/WP14384.PDF Accessed: 20 January 2015.

31. Mercer DE Adoption of agroforestry innovations in the tropics: A review Agroforestry Systems 2004; 61: 311-328.

32. Taye M Evaluating Capacity Development for Local Participation: The \#Khoadi ||Hôas Conservancy Experience. Final Report for International Development Research Center (IDRC). University of British Columbia School of Community and Regional Planning, 2006. 